\title{
INFLUENCE OF THE TYPE AND NUMBER OF PREPREG LAYERS ON THE FLEXURAL STRENGTH AND FATIGUE LIFE OF HONEYCOMB SANDWICH STRUCTURES
}

\author{
VPLIV VRSTE IN ŠTEVILA PLASTI NA UTRDITEV UPOGIBNE \\ TRDNOSTI IN ZDRŽLJIVOSTI PRI UTRUJANJU SATASTIH \\ SENDVIČNIH KONSTRUKCIJ
}

\author{
Ladislav Fojtl' ${ }^{1}$, Sona Rusnakova ${ }^{1}$, Milan Zaludek ${ }^{1}$, Vladimír Rusnák ${ }^{2}$ \\ 1Faculty of Technology, TBU in Zlín, Nad Stranemi 4511, 76005 Zlín, Czech Republic
${ }^{2}$ Faculty of Metallurgy and Materials Engineering, VŠB-Technical University of Ostrava, 17. listopadu 15, 70833 Ostrava-Poruba, Czech \\ Republic \\ fojtl@ft.utb.cz
}

Prejem rokopisa - received: 2014-07-29; sprejem za objavo - accepted for publication: 2014-09-18

doi: $10.17222 /$ mit.2014.124

This research paper deals with an investigation of the flexural properties measured in a three-point bending test depending on the type and number of the E-glass prepreg layers applied to the facing sides of the resulting sandwich structure used for floor panels in the transport industry. The values of the low-cycle fatigue were measured according to the values of the flexural strength obtained from the static test. Cycling was performed at $(70,60$ and 50) \% values of the ultimate flexural load. Moreover, a decrease in the flexural strength and stiffness depending on the number of cycles was also studied. For the production of samples, one type of aluminum honeycomb core and various phenolic prepregs with different numbers of layers were used. These samples were produced with two, in practice commonly used methods - compression molding and vacuum bagging. The measured results show that the production technology has a certain influence on the mechanical behavior in bending and the fatigue life of sandwich structures. The experimental results proved that the type of prepreg (defined by the reinforcing fabric and the amount of resin) and the number of layers also affect the properties of these structures. All the obtained results provide useful information for designing the sandwich structures for the transport industry.

Keywords: sandwich structure, honeycomb, prepreg, fatigue, flexural strength, flexural stiffness

Članek obravnava preiskave lastnosti pri upogibu, izmerjene s tritočkovnim upogibnim preizkusom, v odvisnosti od vrste in števila plasti E-stekla na utrditev, uporabljenih na čelni strani sendvičnih konstrukcij, ki se uporabljajo v transportu za talne plošče. Vrednosti malociklične utrujenosti so bile izmerjene skladno z vrednostmi upogibne trdnosti, dobljenimi pri statičnem preizkusu. Ciklično obremenjevanje je bilo izvršeno pri (70, 60 in 50) \% vrednosti upogibne trdnosti. Poleg tega je bilo preučevano tudi zmanjšanje upogibne trdnosti in togosti v odvisnosti od števila ciklov. Za pripravo vzorcev je bila uporabljena ena vrsta sataste osnove iz aluminija in različne fenolne plasti za utrjenje $\mathrm{z}$ različnim številom plasti. Ti vzorci so bili izdelani z dvema običajnima metodama - s tlačnim litjem in vakuumskim pakiranjem. Izmerjeni rezultati kažejo, da ima tehnologija izdelave določen vpliv na mehansko vedenje pri upogibanju in utrujanju sendvičnih konstrukcij. Rezultati eksperimentov so pokazali, da vrsta plasti za utrjanje (določena s tkanino za utrjanje in količino smole) in število plasti tudi vplivata na lastnosti teh konstrukcij. Vsi dobljeni rezultati zagotavljajo koristne informacije za konstruiranje sendvičnih konstrukcij v transportni industriji.

Ključne besede: sendvične konstrukcije, satje, plast za utrjanje, utrujenost, upogibna trdnost, upogibna togost

\section{INTRODUCTION}

Sandwich structures belonging to a large group of composite materials are applied in many industry sectors such as transportation (interior or exterior parts), construction (insulation elements) and aviation (supporting elements or parts in the interior). With an expanding area of application, durability requirements on sandwich structures also increase. The most often used core materials are polymeric foams, honeycombs or, alternatively, cork and balsa, whereas the face materials are metals, aluminum sheets, HPL sheets and fiber laminates or prepregs (pre-impregnated laminates). ${ }^{1,2}$

Prepregs differ in the type of material (glass, Kevlar, carbon) and in the fabric weight depending on the type of the weave, in which the fibers are arranged. Further- more, different types of resin such us phenol, epoxy, bismaleimide (BMI) and cyanide are used for the impregnation of prepreg fabrics. ${ }^{3}$

During their use, these structures are most often subjected to the bend or impact stress, where the maximum flexural stress is carried by the face material, while the core is barely stressed. This flexural stress leads to the compression of the structure on one side and the tension on the other side, while the core carries only the shear stress. It can be said that sandwich materials stand out particularly for a large flexural stiffness, a flexural strength and a high impact resistance, while having the minimum mass. ${ }^{4}$

In some applications, sandwich structures are subjected to repeated loading, where, more than in the previous cases, all the structural properties depend not only 
on the materials used, but also on the quality of their connections with the unit. Cyclic loading produces a considerable decrease in the strength and modulus; this decrease is called the fatigue. The fatigue strength is strongly dependent on the quality of the connections of individual components creating a sandwich structure, namely, on the interface between the core and the prepreg fabrics. The start of a material failure during fatigue is characterized by the creation of small cracks (in most cases invisible to naked eye), which gradually connect and extend through the sample. In these cracks, a stress concentration causes their rapid growth continuing to a sudden fracture..$^{2,5}$

The results of the experiments are used for a construction of $S-N$ diagrams, which show the number of cycles $(N)$ that a structure can withstand at a certain loading value $(S)$. Due to these diagrams we can predict the durability of sandwich structures during their application.

The research of sandwich structures and their behavior during dynamic loading has been the subject of many studies for a long time. Previous research was focused on the influence of the thickness of the adhesive layer on the sandwich fatigue strength ${ }^{6,7}$, or on the study of the creation and propagation of the cracks in foam cores. ${ }^{8-11}$

However, no previous research was focused on the prepreg materials in combination with aluminum honeycombs, specifically on the dynamic behavior of these structures. The aim of the presented research is to investigate the influence of the type of pre-impregnated fabric and the number of layers in the facings on the static and cyclic flexural behaviors of honeycomb sandwich structures. The effect of the manufacturing technology on the static and dynamic properties of the prepared structures is also evaluated with the experimental measurements.

\section{EXPERIMENTAL WORK}

\subsection{Materials}

The researched sandwich structures were composed of different prepreg materials for the inner and outer facing layers and an aluminum honeycomb core with a hexagonal cell shape. E-glass prepregs PHG840NG213-40 (P1) and PHG840N-F300-47 (P2), both impregnated with phenolic resin, were obtained from the Gurit company and honeycomb ECM 6.4-82 (H1) was from the Euro-Composites company. The latter prepreg was used to verify its excellent adhesion to aluminum honeycombs stated by the producer. The important parameters of the materials are presented in Table 1. The prepreg materials were chosen due to their use for rail interiors resulting from their excellent FST (fire-smoketoxicity) behavior.

A total of four different sandwich structures were prepared from the above materials. Sample A was formed of two outer layers of PHG840-G213-40, the ECM 6.4-82 core and one inner layer of the same prepreg. Sample B had the same composition, but two layers of PHG840-G213-40 were used for the inner layer. Sample C consisted of layers of both PHG840G213-40 and PHG840N-F300-47 (the latter was closer to the core). These samples (A, B, C) were produced with vacuum bagging. The last sample, $\mathrm{D}$, had absolutely the same composition as sample A, but was produced with compression molding.

Table 1: Parameters of prepreg materials and honeycomb Tabela 1: Parametri plasti za utrditev in satje

\begin{tabular}{|c|c|c|c|c|}
\hline Materials & $\begin{array}{c}\text { Fabric mass } \\
\mathrm{g} / \mathrm{m}^{2}\end{array}$ & $\begin{array}{c}\text { Resin mass } \\
\text { content } w / \%\end{array}$ & $\begin{array}{c}\text { Cell size } \\
\mathrm{mm}\end{array}$ & $\begin{array}{c}\text { Density } \\
\mathrm{kg} / \mathrm{m}^{3}\end{array}$ \\
\hline P1 & 820 & 40 & - & - \\
\hline P2 & 300 & 47 & - & - \\
\hline H1 & - & - & 6.4 & 82 \\
\hline
\end{tabular}

\subsection{Preparation of sandwich samples}

As mentioned above, samples A, B and C were prepared with vacuum bagging, while sample D with compression molding. The production using vacuum bagging followed the standard procedure, when, after achieving a sufficient value of vacuum $(0.8 \mathrm{MPa})$, the whole assembly was placed into a curing oven. The samples were heated, in $60 \mathrm{~min}$, from $23{ }^{\circ} \mathrm{C}$ to $130{ }^{\circ} \mathrm{C}$ and then held isothermally in the oven for $120 \mathrm{~min}$. Conversely, compression molded sample D was placed into a laboratory press heated to $160{ }^{\circ} \mathrm{C}$ and compressed with a pressure of $2.5 \mathrm{MPa}$ for $10 \mathrm{~min}$.

\subsection{Flexural tests}

A static flexural test (a three-point bending test) was performed and evaluated according to EN 2746 on a ZWICK 1456 testing machine. The samples were placed on the supports (radius $R=5 \mathrm{~mm}$ ) with a distance of 120 $\mathrm{mm}$ between each other, and the crosshead speed was set to $10 \mathrm{~mm} / \mathrm{min}$. Totally, at least 5 samples were tested to obtain the average ultimate load for each type of structure. Fatigue tests were performed according to ČSN 640618 on an Instron 8871 . The setting of this machine was based on the previously performed tests, according to which an appropriate loading frequency of $3 \mathrm{~Hz}$ was selected. This frequency was also selected to prevent a rise in the local temperature in a specimen during the testing. ${ }^{7}$ The course of the loading was set to pressure pulsating, where the medium load of oscillation $\left(F_{\mathrm{o}}\right)$ and the amplitude of the oscillation load $\left(F_{\mathrm{a}}\right)$ were also set in the software (Figure 1).

The intensity of force $F_{\mathrm{o}}$ was derived from static ultimate load $F_{\max }$. Specific values are given in Table 2. In both of these tests, flat sandwich samples with the dimensions of $150 \mathrm{~mm} \times 20 \mathrm{~mm}$ were used. All the experiments were conducted at room temperature $((23 \pm 1)$ $\left.{ }^{\circ} \mathrm{C}\right)$. 

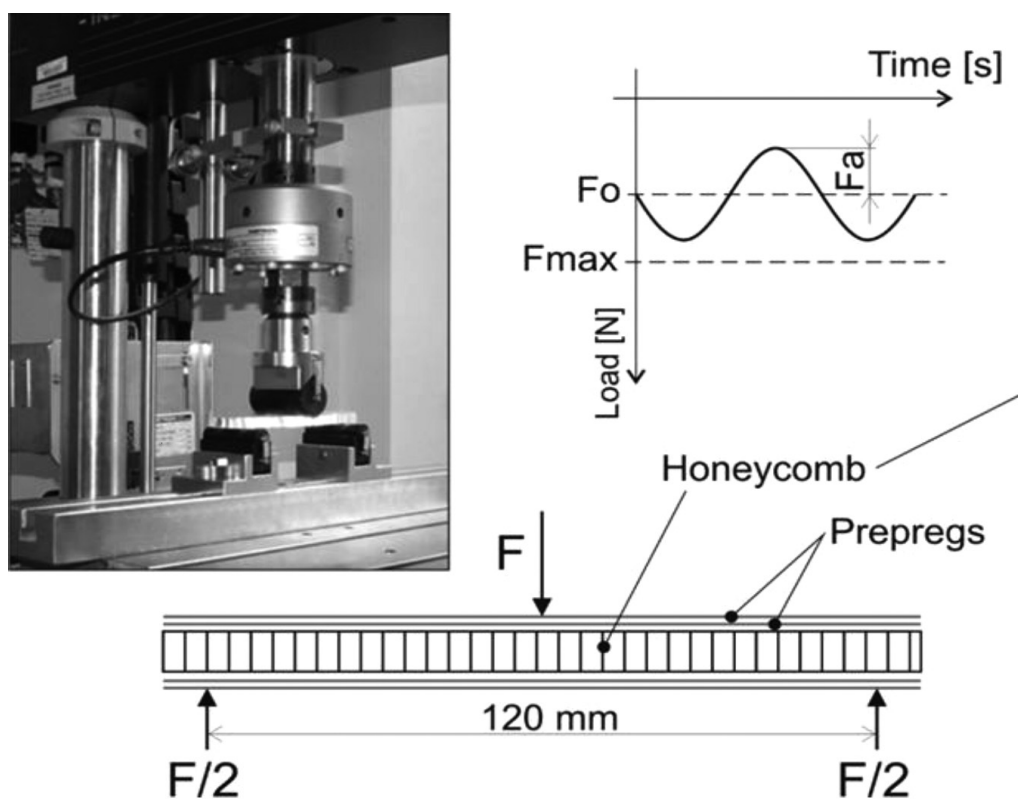

Figure 1: Set-up of the testing machine for flexural fatigue tests

Slika 1: Sestav preizkusne naprave za preizkuse utrujanja pri upogibu

Table 2: Set-up of the loads for fatigue tests

Tabela 2: Nastavitev obremenitev pri preizkusu utrujanja

\begin{tabular}{|c|c|c|c|c|c|}
\hline & $\begin{array}{l}\text { Medium } \\
\text { load of } \\
\text { oscilation } \\
F_{0}(\mathrm{~N})\end{array}$ & $\begin{array}{l}\text { Amplitude } \\
\text { of osci- } \\
\text { lation load } \\
F_{0}(\mathrm{~N})\end{array}$ & & $\begin{array}{l}\text { Medium } \\
\text { load of } \\
\text { oscilation } \\
F_{0}(\mathrm{~N})\end{array}$ & $\begin{array}{l}\text { Amplitude } \\
\text { of osci- } \\
\text { lation load } \\
F_{0}(\mathrm{~N})\end{array}$ \\
\hline \multirow{3}{*}{ 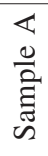 } & 200 & \pm 150 & \multirow{3}{*}{ 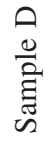 } & 210 & \pm 160 \\
\hline & 175 & \pm 125 & & 180 & \pm 130 \\
\hline & 150 & \pm 100 & & 155 & \pm 105 \\
\hline
\end{tabular}

\section{RESULTS AND DISCUSSION}

\subsection{Static flexural test}

The three-point bending test was conducted to obtain the values of the average ultimate flexural loads $\left(F_{\max }\right)$, which are shown in Figure 2, including the error bars (showing the minimum and maximum values) and the standard deviations. As can be seen, the highest value of the ultimate flexural load was measured for sample C

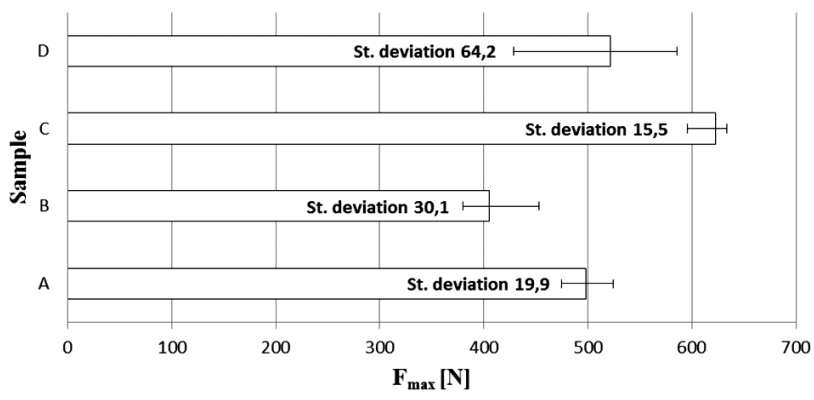

Figure 2: Average ultimate flexural loads for individual sandwich structures

Slika 2: Povprečje največjih upogibnih obremenitev za posamezne sendvične konstrukcije having one layer of prepreg PHG840N-F300-47 in each facing. The results for this sample also show the lowest value of the standard deviation. In contrast, sample B, which has the same number of prepreg layers in the facings, shows about a $35 \%$ lower value of the ultimate flexural load compared to sample C. It is also necessary to note that the fabric weight of the second prepreg is more than 2.5 times higher and that both preprags differ in the fabric weave style. Comparing samples A and D, manufactured with different technologies, we find that the samples manufactured with compression molding show higher average values of the ultimate flexural loads. However, these values are burdened with a higher variance leading to a three-time higher standard deviation compared to the values obtained for sample A.

\subsection{Flexural-fatigue test}

The experiment for fatigue tests was based on the values of $F_{\max }$. The medium loads of oscillation $\left(F_{\mathrm{o}}\right)$ were set as $(40,35$ and 30$) \%$ of the measured $F_{\max }$, where the maximum applied loads during the sinusoidal loading $\left(F_{\mathrm{o}}+F_{\mathrm{a}}\right)$ were equal to $(70,60$ and 50$) \%$ of $F_{\text {max }}$. Table 2 shows the specific-value set for cycling. Repeated loading was performed only for samples A and $\mathrm{D}$ to validate the influence of the production technology on the static and dynamic properties of the sandwich structures with identical material composition.

Fatigue curves were obtained from the measured data using an estimation of a logarithmic regression. This type of regression showed the highest value of reliability parameter $R^{2}$. The resulting curves obtained from the measured data are presented in Figure 3. For $F_{\mathrm{o}}+F_{\mathrm{a}}$ corresponding to $60 \%$ of $F_{\max }$ sample A shows a greater number of cycles compared to sample D, similarly as in 


\section{FOJTL et al.: INFLUENCE OF THE TYPE AND NUMBER OF PREPREG LAYERS ON THE FLEXURAL ...}

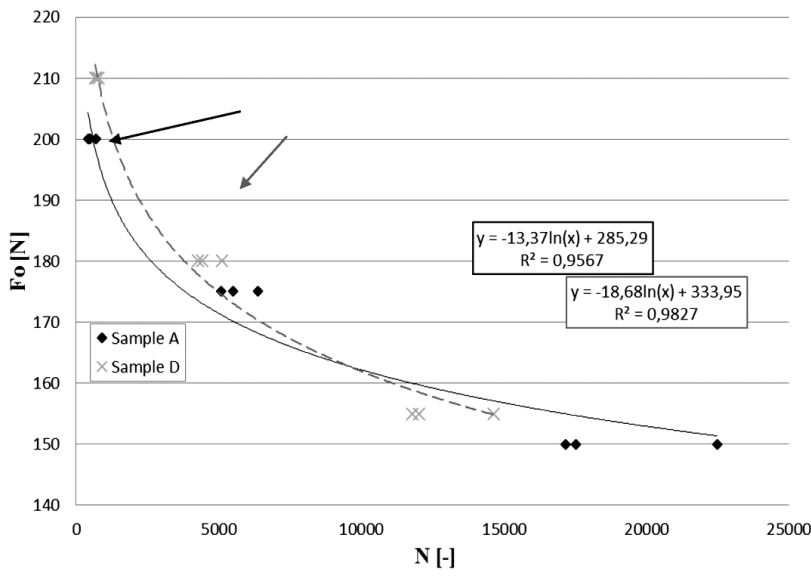

Figure 3: Fatigue curves for the samples produced with different production technologies

Slika 3: Krivulje utrujanja pri vzorcih, izdelanih po različnih tehnologijah

the case of $F_{\mathrm{o}}+F_{\mathrm{a}}=50 \%$ of $F_{\max }$. During this loading, sample A survived nearly 3000 cycles more than the other sample. In contrast, the number of cycles measured for $F_{\mathrm{o}}+F_{\mathrm{a}}$ corresponding to $70 \%$ of $F_{\max }$ is not significantly different.

Furthermore, the cycling with the maximum applied load $\left(F_{\mathrm{o}}+F_{\mathrm{a}}\right)$ corresponding to $70 \%$ of $F_{\max }$ was performed for samples $\mathrm{B}$ and $\mathrm{C}$ in order to obtain the values of the flexural modulus and the tensile strength after (5000, 10000 and 15000) cycles. After these numbers of cycles, a single statistic flexural test was performed. The measured data are shown in the following figure, which also gives the results of the static test $(N=1)$.

A decrease in the flexural modulus - E(f) - for samples B and C is depicted in Figure 4. Both samples show an almost identical decrease of $25 \%$ in the modulus after 5000 cycles. As can be seen, after 10000 and also after 15000 cycles, sample B does not exhibit any significant decline in the modulus. On the contrary, sample $\mathrm{C}$ shows a downward trend in the flexural modulus, by approximately $5 \%$ per each additional 5000cycle set.

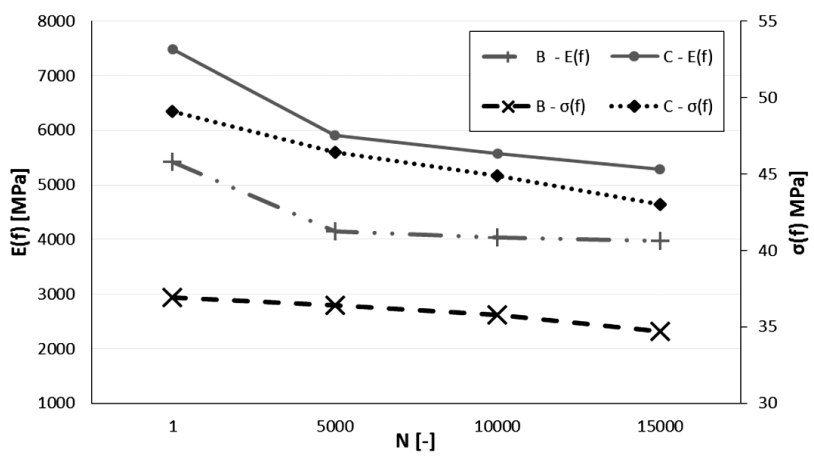

Figure 4: Decrease in flexural modulus $-E(\mathrm{f})$ and flexural strength $\sigma(\mathrm{f})$ for samples B and C

Slika 4: Zmanjšanje modula upogiba $E(f)$ in upogibne trdnosti $\sigma(f)$ pri vzorcih $\mathrm{B}$ in $\mathrm{C}$
The decline in the flexural strength $-\sigma(\mathrm{f})-$ is not so significant. As depicted in the same figure, a more significant decrease again occurs in sample $\mathrm{C}$ with prepreg PHG840N-F300-47 containing the fabric with a lower areal weight and a greater amount of resin. This decrease is equal to approximately $2 \mathrm{MPa}$ after every 5000 cycles. The strength after 15000 cycles decreased to $88 \%$ of the original value from the static test. Conversely, the decrease for sample B is in tenths of $\mathrm{MPa}$, where the strength after 15000 cycles is equal to $94 \%$ of the original value obtained from the static test.

\section{CONCLUSIONS}

The research evaluated the influences of the type and the number of the prepreg layers on the flexural properties and the bending fatigue. The results indicate that the type (characterized by the type of reinforcing fabric and resin content) significantly affects the lifetime of sandwich structures under cyclic bending. The experiments showed that the usage of a prepreg with a larger resin amount and a lower fabric weight leads to a significant increase in the fatigue lifetime, generally by $25 \%$. This is apparently caused by the creation of a larger contact area between the prepreg fabric and the honeycomb cells due to the leak of a larger amount of resin and the formation of a larger radius of resin in the corner between the cells and the prepreg fabric. However, it must be noted that the fabric weave style in the prepreg can also influence the bending behavior of sandwich structures. The research further revealed that the technology with which a sandwich structure is prepared has a certain influence on the mechanical properties of this structure. It was found that the compressionmolding technology, which is very productive and less demanding on the support materials in comparison to vacuum bagging negatively effects the fatigue lifetime. However, all the previous conclusions are valid only for the structures studied by the authors. In order to apply the results in practice and make the final conclusions, it is necessary to prepare new sandwich structures composed of different types of prepreg materials with a varying resin amount and also use honeycombs with different cell sizes.

\section{Acknowledgement}

This study was supported by an internal grant of TBU in Zlín, No. IGA/FT/2015/001, funded from the resources for specific university research. Furthermore, the article was written with the support of the Operational Program Research and Development for Innovations co-funded by the ERDF and the national budget of the Czech Republic, within the framework of project Centre of Polymer Systems (reg. number: CZ.1.05/2.1.00/ 03.0111). 


\section{FOJTL et al.: INFLUENCE OF THE TYPE AND NUMBER OF PREPREG LAYERS ON THE FLEXURAL ...}

\section{REFERENCES}

${ }^{1}$ D. Zenkert, Nordic Industrial Fund, The Handbook of Sandwich Construction, 1st ed., EMAS Publishing, Worcestershire, UK 1997

${ }^{2}$ T. N. Bitzer, Honeycomb Technology: Materials, Design, Manufacturing, Applications and Testing, 1st ed., Chapman \& Hall, London, UK 1997

${ }^{3}$ HexPly® Prepreg Technology [online], 2014, [cited 2014-28-05] Available from World Wide Web: http://www.hexcel.com/resources/ technology-manuals

${ }^{4}$ J. R. Vinson, The Behavior of Sandwich Structures of Isotropic and Composite Materials, 1st ed., CRC Press, New York, USA 1999

${ }^{5}$ M. Burman, Fatigue crack initiation and propagation in sandwich structures, Dissertation thesis, Royal Institute of Technology, Stockholm, 1998

${ }^{6}$ Y. Jen, L. Chang, Effect of thickness of face sheet on the bending fatigue strength of aluminum honeycomb sandwich beams, Engineering Failure Analysis, 16 (2009), 1282-1293, doi:10.1016/ j.engfailanal.2008.08.004
${ }^{7}$ Y. Jen, Ch. Ko, H. Lin, Effect of the amount of adhesive on the bending fatigue strength of adhesively bonded aluminum honeycomb sandwich beams, International Journal of Fatigue, 31 (2009), 455-462, doi:10.1016/j.ijfatigue.2008.07.008

${ }^{8}$ B. Shafiq, A. Quispitupa, Fatigue characteristics of foam core sandwich composites, International Journal of Fatigue, 28 (2006), 96-102, doi:10.1016/j.ijfatigue.2005.05.002

${ }^{9}$ M. Burman, D. Zenkert, Fatigue of foam core sandwich beams-1: undamaged specimens, International Journal of Fatigue, 19 (1997), 551-561, doi:10.1016/S0142-1123(97)00069-8

${ }^{10}$ M. K. Farooq, A. El Maihi, S. Sahraoui, Modelling the flexural behaviour of sandwich composite materials under cyclic fatigue, Materials \& Design, 25 (2004), 199-208, doi:10.1016/j.matdes.2003. 09.022

${ }^{11}$ N. Kulkarni, H. Mahfuz, S. Jeelani, L. A. Carlsson, Fatigue crack growth and life prediction of foam core sandwich composites under flexural loading, Composite Structures, 59 (2003), 499-505, doi:10.1016/S0263-8223(02)00249-0 